evaluate various proposals for reform the college drew up a list of 16 criteria. ${ }^{1}$ It came down against throwing more money at the problem-as this could make things worse-and urged extreme caution over building on the present structure. What was needed was a thoughtful re-examination of the system of health care from top to bottom.

So far the college has decided that the solution will be a nationwide programme, and it wants such a programme adopted as a policy goal for the nation. The college's main focus now is to define further the systemic reforms that are needed. To make the reform of health care a reality the college has identified two primary objectives: to further an environment receptive to comprehensive reform and to speak from a well informed position. On each of the main issuescontaining costs, controlling use, determining benefits, deciding on mechanisms of financing, and reducing administrative costs - work is continuing deliberately and carefully.

According to the American College of Physicians nothing short of universal access to basic health care will be fair in the long run. How that goal is achieved has yet to be determined, although the college believes that it has identified its principal elements and proposed some realistic options. These are currently being reviewed by the members of the college, and the final proposals should be published next spring. America, it believes, can one day develop a system that is fair and equitable for all.

NORTON J GREENBERGER President 1990-1

NICHOLAS E DAVIES* President Elect 1990-1

EUEGENE A HILDRETH

American College of Physicians, Chairman, Board of Regents 1990-1

USA

(Correspondence to Dr Greenberger, Department of Medicine, University of Kansas Medical Centre, Kansas City, Kansas 66103, USA)

$\star$ Dr Davies died earlier this year.

1 American College of Physicians. Access to health care. Ann Intern Med 1990;112:641-61.

\title{
Does triamterene cause renal calculi?
}

\section{Not enough evidence yet to tell patients to stop taking triamterene}

Over two million prescriptions for triamterene were issued in the United Kingdom last year so the possibility that this drug may cause renal calculi is important. As a potassium sparing diuretic triamterene is often prescribed in conjunction with a thiazide and acts on the distal tubule to inhibit reabsorption of sodium in exchange for potassium and hydrogen ions. Taken by mouth it is rapidly metabolised to parahydroxytriamterene and then to parahydroxytriamterene sulphate. Half of the drug is excreted in the urine, $20 \%$ as triamterene and $80 \%$ as metabolite. ${ }^{1}$

A case report in 1979 suggested the lithogenic properties of triamterene, ${ }^{2}$ and this was followed by the observation of an abnormal urinary sediment in patients and volunteers taking the drug. ${ }^{3}$ The sediment, resembling granular casts, was often deep brown and accompanied by hyaline casts, some of which were covered with small birefringent crystals; larger round brown bodies, appearing as Maltese crosses under polarised light, were also seen. This abnormal urinary sediment occurs in about half of all patients treated. ${ }^{+}$The crystals appear in the urine two to four hours after ingestion of the drug, and animal studies show that birefringent crystals and casts form within the medullary and papillary collecting ducts of the kidney. ${ }^{5}$ This site of formation is supported by the histological findings in a patient who developed acute interstitial nephritis after massive intoxication with triamterene and hydrochlorothiazide. Tubular plugging by crystal laden tubular cells was found in renal tissue, although the crystals were not positively identified as containing triamterene or a metabolite. ${ }^{6}$ Nevertheless, only one definite case of interstitial nephritis induced by triamterene has been reported.

The presence of triamterene in a calculus may be suspected by blue fluorescence $(440 \mathrm{~nm})$ under long wave ultraviolet light, but thin layer chromatography ${ }^{8}$ or infrared spectroscopy provides definitive analysis. ${ }^{1}$ The composition of the stones varies: half of 66 stones containing triamterene were found to contain less than $5 \%$ and none contained more than $75 \%$ of material derived from the drug. ${ }^{8}$ Triamterene itself, rather than its more abundant metabolites, was the commonest constituent. Others have also identified stones made mostly from triamterene ${ }^{9}$ and Carr et al found that $21 \%$ of stones containing triamterene were made exclusively of it. ${ }^{1}$ In the remainder triamterene was associated with calcium oxalate monohydrate and dihydrate, apatite, or uric acid.

But do these data mean that triamterene or its metabolites cause the stones? Triamterene is not invariably found at the core of every stone, ${ }^{1}$ and Werness et al showed that triamterene and metabolites have no effect on calcium oxalate monohydrate, hydroxyapatite, or uric acid crystal systems, although they bind strongly to protein matrix. ${ }^{10}$ In contrast, White and Nancollas showed that triamterene and its metabolites could induce growth of crystals in supersaturated solutions of calcium oxalate monohydrate. ${ }^{11}$ The clinical relevance of these in vitro findings is not clear, and, most importantly, stones in the urinary tracts of patients taking triamterene do not always contain the drug. ${ }^{12}$

If crystalluria and casts are common sequelae to ingestion of triamterene might absorption or excretion be perhaps different in patients in whom stones form? Carey et al found no difference in absorption or excretion of triamterene in such patients, ${ }^{13}$ and this was confirmed by Ettinger, who also found no difference between patients and controls in total recovery, hourly excretion patterns, or concentration of triamterene or parahydroxytriamterene in the urine.$^{1+}$ The $\mathrm{pH}$ of urine does not seem to affect the solubility of triamterene or its sulphate metabolite. ${ }^{1}$ More relevantly, Carey et al point out that those in whom calculi form early during treatment and with a family history are more prone to further calculi; this may explain their observation of a $35 \%$ incidence of previous renal calculi in patients who developed calculi while being treated with triamterene compared with a $4 \%$ incidence of previous calculi in patients who did not. ${ }^{13}$ So perhaps the patient, rather than the drug, is the risk factor.

A specific lithogenic role for triamterene, and possibly its metabolites, remains unproved, although the occurrence of stones rich in triamterene must tend to support one. The evidence is not strong enough to warrant patients with a history of recurrent renal calculi avoiding taking the drug, but with increasing use further epidemiological information may become available. Currently in one reference laboratory stones containing triamterene are as common as cystine 
stones, ${ }^{1}$ and as a cause of radiolucent filling defects in intravenous urograms they must not be forgotten.

ROBIN G WOOLFSON

Lecturer in Nephrology

MARTIN A MANSELL

Consultant Nephrologist

St Peter's Centre for Nephrology and Urology,

St Philip's Hospital, London WC2A 2EX.

Carr MC, Prien EL, Babayan RK. Triamterene nephrolithiasis: renewed attention is warranted. f Urol 1990;144:1339-40.

Ettinger B, Weil E, Mandel NS, Darling S. Triamterene-induced nephrolithiasis. Ann Intern Med 1979;91:745-6.

Fairley KF, Birch DF, Haines I. Abnormal urinary sediment in patients on triamterene. Lancet 1983;i:421-2.
4 Spence JD, Wong DG, Lindsay RM. Effects of triamterene and amiloride on urinary sediment in hypertensive patients taking hydrochlorothiazide. Lancet 1985; ii:73-5.

5 Fairley KF, Woo KT, Birch DF, Leaker BR, Ratnaike S. Triamterene-induced crystalluria and cylinduria: clinical and experimental studies. Clin Nephrol 1986;26:169-73.

6 Farge D, Turner MW, Roy DR, Jothy S. Dyazide-induced reversible acute renal failure associated with intracellular crystal deposition. Am $\mathcal{F}$ Kidney Dis 1986;6:445-9.

Bailey RR, Lynn KL, Drennan CJ, Turner GAL. Triamterene-induced interstitial nephritis. Lancet $1982 ; \mathrm{i}: 226$.

8 Sorgel F, Ettinger B, Benet LZ. The true composition of kidney stones passed during triamterene therapy. $f$ Urol $1985 ; 134: 871-3$.

9 Dickstein E, Loeser WD. Triamterene calculus. $\mathcal{F}$ Urol 1985;133:1019.

10 Werness PG, Bergert JH, Smith LH. Triamterene urolithiasis: solubility, pK, effect on crystal formation, and matrix binding of triamterene and its metabolites. 7 Lab Clin Med 1982;99:254-62.

11 White DJ, Nancollas GH. Triamterene and renal stone formation. 7 Urol 1982;127:593-7.

12 Jick H, Dinan BJ, Hunter JR. Triamterene and renal stones. $\mathcal{F}$ Urol 1982;127:224-5.

13 Carey RA, Beg MMA, McNally CF, Tannenbaum P. Triamterene and renal lithiasis: a review. Clin Ther 1984;6:302-9.

14 Ettinger B. Excretion of triamterene and its metabolite in triamterene stone patients. 7 Clin Pharmacol 1985;25:365-8.

\section{Manslaughter convictions for making mistakes}

\section{The real lessons are for training and supervision}

Were the two young doctors found guilty of manslaughter over the death of a 16 year old patient with leukaemia rightly convicted? That question may ultimately have to be decided by the House of Lords. Appeals by Barry Sullman, aged 27, and Michael Prentice, aged 25, against their convictions could go to the highest court in the land.

Dr Prentice was a preregistration house officer at Peterborough General Hospital in March 1990 when he injected vincristine (which should have been administered intravenously) into the spine of 16 year old Malcolm Savage, a leukaemia sufferer since the age of 4 . Dr Sullman, then a senior house officer in general medicine, supervised. A washout performed after the mistake was realised was unsuccessful and the patient died.

Malcolm Savage was scheduled to receive methotrexate intrathecally and vincristine intravenously. Dr Prentice was told by ward staff that the patient was coming in for his normal lumbar puncture. Neither he nor Dr Sullman had been given any "cockpit drill" on administering drugs. Dr Prentice had never performed a lumbar puncture on an adult and asked Dr Sullman to supervise the procedure. Dr Sullman told the police that he believed he was being asked only to supervise the lumbar puncture not the administration of vincristine, with which he was unfamiliar.

To justify a manslaughter charge, death has to be caused not just negligently but recklessly. But what constitutes recklessness? The judge directed the jury that they should convict if satisfied, firstly, that the defendants created an obvious and serious risk of causing serious harm, and secondly, that they gave no thought to that risk.

The judge felt constrained' to give that direction because of two House of Lords cases in 1982 in which the law lords said a defendant could be reckless not only where he knew of a risk of physical harm and nevertheless went on to take it, but also where he gave no thought to the possibility of such a risk.

Lawyers for Drs Prentice and Sullman will argue on appeal that this direction, laid down in a case of reckless driving, should not apply in their case. ${ }^{1}$ Their behaviour, their lawyers contend, amounted to no more than "ordinary" medical negligence.

If the House of Lords test stands, arguably it will be the least experienced doctors - those who know so little that an obvious risk never occurs to them - who will be most likely to fall foul of the criminal law. There have been five previous cases in the UK where vincristine has been injected intrathecally, in three of which the patient died. In each case the doctor administering the treatment was in a better position to know the risks than Drs Sullman and Prentice. One was an experienced senior house officer in oncology, the second an experienced registrar in haematology, and the third a senior house officer in haematology. None was prosecuted.

In the Peterborough case and at least one of the others vincristine and methotrexate were brought into the ward in the same box or bag. Staff at Peterborough told the court they were unaware of published articles warning against this practice.

The data sheet for vincristine states that it should be administered only by or under the supervision of a physician experienced in cytotoxic chemotherapy. The General Medical Council's recommendations for the training of house officers say they should be supervised by a senior registrar, registrar or senior house officer in the particular specialty. Both juniors were in general medicine, not haematology. The hospital's own handbook for the administration of intravenous drugs imposes an obligation on prescribers of such drugs to make sure that whoever administers them is fully aware of their nature and purpose. It appeared from the evidence that Dr Prentice was told about the problems in administering cytotoxic drugs but was not made aware of the potentially lethal effects.

The consultant haematologist caring for Malcolm Savage told the court he was not aware that Dr Prentice would be administering the drugs. If asked, he would have said that the house officer was not a suitable person to do this, nor $\mathrm{Dr}$ Sullman to supervise. A registrar in general medicine told the court he encouraged Dr Prentice and said he should give the injections if supervised. He told him to ask Dr Sullman to supervise if he had done a lumbar puncture before; otherwise he (the registrar) would supervise.

Bringing the full weight of the criminal law to bear on two fledgling doctors will do little to remedy a system which lets juniors loose on patients with too little training, too little support, and too little sleep. As $\mathrm{Mr}$ Justice Owen said in passing sentence, "It seems to me that you could have been helped much more than you were helped. This could have ensured that this particular tragedy never happened."

Legal correspondent,

CLARE DYER 